been made as follows: Dr. R. N. Brothers, senior lecturer in petrology, University of Auckland, to enable him to examine at the Imperial College, London, the application of erystalline and deformation theories for certain New Zealand ultrabasic rocks to a group of related rocks which occur in Great Britain, for a year from November 1959; Dr. J. W, Clark-Lewis, senior lecturer in organic chemistry, University of Adelaide, to enable him to continue a study of the chemistry of natural products, with particular reference to the stereochemistry of flavan derivatives, at the Imperial College, London, for seven months from October 1960; Dr. A. W. Crompton, director of the South African Museum, Cape Town, to enable him to study mammalian palæontology at Cambridge and the British Museum (Natural History) for four months during 1960; Dr. J. C. Gould, senior lecturer in bacteriology, University of Edinburgh, to enable him to extend his studies of staphylococcal infections and make comparative studies in an African community, in Nigeria, during May-September 1960; Prof. K. R. L. Hall, professor of psychology, University of Bristol, to enable him to carry out a field-study of behaviour and social organization of wild baboon groups in differing environments in South and South-West Africa, during July-September 1960; Dr. L. M. Jackman, lecturer in organic chemistry, Imperial College, London, to enable him to investigate hydrogen bonding in organic molecules by nuclear magnetic resonance spectroscopy, at Adelaide, during JulyOctober 1960 ; Prof. D. O. Jordan, Angas professor of physical and inorganic chemistry, University of Adelaide, to assist him to visit University College, London, and the Royal Cancer Hospital, London, during February-September 1960, in order to study new techniques and particularly those concerned with the structure, behaviour and functioning of biological macro-molecules; Prof. H. Kleerekoper, professor of zoology, McMaster University, to assist him in completing during the summer of 1960 an investigation of bottom sediment cores of Lake Moneague, Jamaica, for which a bursary was awarded to him in April 1958 ; Mrs. Beryl E. March, instructor and research associate, Department of Poultry Science, University of British Columbia, to assist her to visit Cambridge during May-August 1960 in order to study methods of evaluating the nutritive value of fish meals ; Dr. E. H. Mercer, of the Chester Beatty Research Institute, London, to enable him to carry out an electron microscopic study of cell division and differentiation in plants, at Sydney, during February-July 1960.

\section{The Liverpool Geological Society}

Throdghout the first three days of 1960 the centenary celebrations of the Liverpool Geological Society, happily combined with the eighth InterUniversity Geological Congress, attracted an enthus. iastic gathering of more than two hundred geologists. The theme of the meetings was "Recent Advances in Geology", and each of ten lectures by speakers from British and foreign universities gave rise to spirited discussion. The Society has now published the text of these addresses in a volume of more than three hundred pages which is a fine contribution to geological literature (Liverpool and Manchester Geol. J., Centenary Issue : price 20s.). In it, T. S. Westoll reviews recent studies on the palæontology of fishes: G. Voll, in a sixty-page paper, summarizes the latest work in the field of petrofabrics; S. I.
Tomkeieff describes sources of information on the geology of the U.S.S.R.; L.M.J.U. van Straaten writes on deltaic sedimentation; R. G. Mason on geophysical investigations of the sea floor; W. S. Mackenzie on experimental studies in petrology; W. C. Krumbein on numerical data in geology; C. F. Davidson on radiogeology and geochronology ; and $R$. H. Cummings on advances in micropalæontology. An essay by W. E. Swinton tells the history of Chirotherium, the reptilian foot-print found in the Triassic rocks of Cheshire (long believed to be the hand-print of a mammal) which is reproduced on the seal and medal of the Society. Liverpool geologists have done well in sponsoring this readable review of present knowledge in some of the most active branches of earth science.

\section{Uranium in South-West England}

THE reconnaissance survey for uranium, carried out by the Atomic Energy Division of the Geological Survey during the past two years, is now virtually complete. Seventy new occurrences of uranium have been found during the course of operations which have included an aerial survey of Cornwall, Devon and much of Somerset, as well as surface mapping, excavating and drilling at promising localities. No deposit of economic importance has been discovered, and it is concluded that if any are present they are covered to such a depth with soil or overburden that they are unlikely to be detected by existing instruments. Although no deposit estimated to contain more than 5 tons of uranium oxide has been found as a result of this survey, the South-West of England uranium province has served for many years as an ideal testing ground for British geological electronic equipment, which is now used extensively throughout the world. The study of uranium occurrences in Cornwall and Devon, started in 1945, has played an important part in the discovery of uranium in the Commonwealth, while recent work has contributed considerably to the development of aeroradiometric surveying techniques.

\section{Scientists and Engineers in American Industry}

The U.S. National Science Foundation has stated that American business firms employed about 780,000 scientists and engineers in January 1959. About 35 per cent of the total were engaged in engineering and scientific research and development activities. Scientists and engineers in the industry sectors included in the current survey are estimated to represent approximately two-thirds of the scientists and engineers employed in the United States. The other third are employed in government agencies, educational institutions, non-profit organizations, and self-employed. Industries employing the largest groups of scientists and engineers in January 1959 were aircraft and parts, electrical equipment, and chemicals and allied products. Each employed more than 75,000 scientists and engineers; combined, they employed one-third of the total number of scientists and engineers in private industry and approximately half the scientists and engineers engaged in the performance or administration of research-and-development activities in private industry. Each of two other industries employed more than 50,000 but less than 75,000 scientists and engineers : machinery (except electrical) and engineoring and architectural services. Next in size, in terms of scientific and engineering employment, were construction, fabricated metal products and ordnance, 